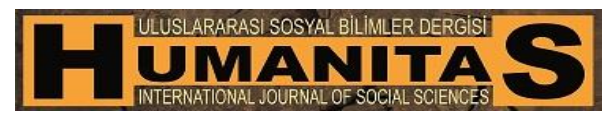

$\begin{array}{ll}\text { Humanitas, 2017; 5(10): 295-314 } & \text { http://humanitas.nku.edu.tr } \\ \text { ISSN: } 2147-088 X & \text { DOI: } 10.20304 / \text { humanitas.316502 }\end{array}$

Araştırma-İnceleme

\title{
GÖRSEL SANATLARDA PARADOKS
}

\section{Mustafa Cevat ATALAY ${ }^{1}$ Melihat TÜZÜN²}

\begin{abstract}
Öz: Sanat eserleri biriciktir. Bu yüzden tekildir. Sanat eserlerinin gizli yönleri vardır. $\mathrm{Bu}$ yüzden sanat eserlerinin analizinde birçok farklı yöntem bulunmaktadır. Sanat eserleri sanatçı üretimi de de olsa varlığını insana ve insanın içinde bulunduğu evrenden alır. Görsel sanatçılar, filozoflar şairler, mucitler, bilim adamları ve yazarlar gibi yaratıcı süreçlerde paradokstan da beslenerek eser üretmektedirler. Bir nesnenin görünen özelliklerinden bazılarını değiştirdiğimizde görsel algımız değişebilmektedir. Resme baktığımızda gözlerimiz beynimize bir görüntü göndermektedir. Bazen beyin bunu yanlış da analiz edebilmektedir. Görsel algıya tam olarak her zaman güvenmek bizim dış dünyayı yorumlamamız esnasında hatalara neden olabilir. $\mathrm{Bu}$ durumlar görsel paradoks olarak değerlendirilebilmektedir. Sanatçılar bu paradoksal denklemleri temalarında kullanarak izleyicide yanılsama oluşturmak isterler. Paradoks algılandığında bir açıklamaya ihtiyaç duyulur.
\end{abstract}

$\mathrm{Bu}$ makalenin amac1, paradoksu yapitlarında tematik olarak kullanan görsel sanatçılardan Partıck Hughes, Maurits Cornelis Esher, Ignatius Widiapradja, Rene Magritte, Chema Madoz' un yapitlarını analiz etmektir. Paradoks içeren iki boyutlu tasarımlarda bir sağaltma sadeleştirme söz konusudur. Bunun yanında görsel sanatçılar genellikle temayı, temel bir takım biçim ve renkler ile sınırlandırılarak sofistike yollara ulaşmada mesajın doğrudan izleyici ile buluşmasını ve düşündürmesini istemektedirler. Bu nedenle görseller izleyici ile birçok farklı iletişime girmektedir. Makalede, Paradoks kavramı literatür bakımından araştırılmıştır. Araştırma, Partıck Hughes, Maurits Cornelis Esher, Ignatius Widiapradja, Rene Magritte, Chema Madoz' e ait on adet görsel ile sınırlandırılmıştır. Seçilen bu görseller içerik konu ve teknik olarak incelenip oluşan veriler ışığında yorumlamalar yapılacaktır.

Anahtar Sözcükler: Sanatçı, Paradoks, Yapıt, Analiz.

\footnotetext{
${ }^{1}$ Doç. Dr., Namık Kemal Üniversitesi, Güzel Sanatlar, Tasarım ve Mimarlık Fakültesi, Resim Bölümü. otantikresim@gmail.com

2 Prof., Namık Kemal Üniversitesi, Güzel Sanatlar, Tasarım ve Mimarlık Fakültesi, Resim Bölümü. melihattuzun@gmail.com
} 


\title{
THE PARADOX IN VISUAL ARTS
}

\begin{abstract}
An art work is unique that's why it's single. Art works have hidden aspects That's the reason why there are many different ways of analyzing artworks. Even though art works are artists' productions, they take their existence from human beings and from the world they are in. Visual artists, philosophers, poets, inventors, scientists and writers are producing works by feeding on paradoxes during the creative processes. When we change some of the visible properties of an object, our visual perception can change.

When we look at the picture, our eyes send an image to our brains but sometimes the brain can misread it. Always fully trusting visual perception can lead to errors during our interpretation of the outside world. These situations can be evaluated as visual paradoxes. Artists use these paradoxical equations in their themes to create illusion in the audience. When the paradox is perceived, an explanation is needed.
\end{abstract}

The purpose of this article is to analyze the artists who used paradox in their works thematically such as Partick Hughes, Maurits Cornelis Esher, Ignatius Widiapradja, Rene Magritte, Chema Madoz. Images depicting the paradox has a universal meaning similarity. Seen also throughout this creations due to the universal perceptions, despite the cultural differences, although at a basic level images of paradox can be perceived and interpreted. There is a simplification in the two dimensional creations including paradox. Furthermore visual artists generally by restricting the theme with some basic shapes and colors, they aim to make the audience meet with the message directly and think about it in order to reach the sophisticated way of it. In this respect the visuals are in contact with the audience in many ways. The article is limited to ten visuals of Partick Hughes, Maurits Cornelis Esher, Ignatius Widiapradja, Rene Magritte, Chema Madoz by investigating the pradox notion in terms of literature. These chosen visuals will be examined in content, subject and technic and interpretations will be made throughout the data.

Keywords: Artist, Paradox, Work of Art, Analysis.

\section{Giriş}

Paradoks parçaları içinde mevcut doğrular olan bir yapının bir çelişki oluşturmasıdır. "Paradoks genelde, her biri ayrı ayrı doğru görünen, fakat görünürde çelişkiyle sonuçlanan bir veya birkaç önermeden oluşur. Bu genel tanım içerisinde farklı biçimleri var. Örneğin, önermeler doğru olup, gerçekten de varılan sonucu ima etmekle birlikte; sonuç aslında bir çelişki olmayıp, önseziyi zorlayan bir durum oluşturmaktadır. " (Altun, 2008, "Paradoks sözcüğü Yunanca para: Karşıt ve doxa: Düşünce, inanış sözcüklerinden oluşmuştur. Paradoksal durumlarda birlikte gerçekleşmesi beklenmeyen iki olgunun ya da birlikte var olması beklenmeyen iki niteliğin bir arada olması söz konusudur." (Kalay\& Göksu, 2003). 
Paradoks mantıksal bir tutarsızlığı barındırır. Genellikle "çelişki”, azınlıkla "yanıltmaç", "çatışkı" olarak ifade edilir. Paradoks dilimize yerleştiği şekliyle yaygın kullanılmaktadır.

"Paradoksun içinde bir çeşit çelişki olduğu doğrudur ama yönü, anlam ve doğruluk değeri paradoksa farklı bir felsefi değer yüklemektedir. Salt çelişkide, çelişen taraflardan biri doğru diğeri yanlış değerine sahiptir. Paradoksun sahip olduğu çelişki zaten bu iki farklı ve zıt değerin ortaya çıkmasından kaynaklanır. Çelişenlerin aynı anda doğru ya da yanlış olması düşünülmez. Yani çift değerli mantığın parçası olan bir önerme ya doğru ya yanlıştır. Paradoksta ortaya çıkan çelişki durumu bundan daha farklıdır." (Hacınebioğlu, 2006).

Mantık, matematik ve felsefe dışında paradoksun kavram olarak bir sorunsal haline gelmesi görsel sanatlarda da vardır. Paradoks sanat eserlerinin de konusu teması ya da biçemi olabilir. Sanat eserlerinde açık paradoksu tema olarak amaç edinmiş ya da gizlenmiş birçok görsel sanatçı ve dolaylı olarak çelişkiye göndermeler yapan birçok sanatçıda vardır. Görsel sanatlarda fotoğrafın da konusuna paradoks konu olmuştur. Barthes "bu görüşten yola çıkarak fotoğrafin "kodsuz mesaj" paradoksu üzerinde durur.", çünkü, Lacan'ın "ifade edilen ile bastırılan" çatışmasında olduğu gibi, imgenin paradoksal bir bilinç oyunu olmadan öylesine görülmesi olanaksızdır, bu oyun bir şeyi aynı anda hem "orada" hem de "orada değil" olarak görebilme yeteneğidir (Türkoğlu, 2000).

Paradoksun sanata ilişkin olarak söylediği şey ise, "Kant'ın sanat açıklamasının temelini oluşturur: Sanat doğa gibi göründügünde güzeldir, fakat biz onun sanat olduğunun bilincinde olmalıyız. Burada sanat açısından ima edilen şudur: Sanat, bir amaçla bağıntı içinde gerçekleştirilen bir insan edimi olmakla birlikte; bu edimin ürünü, o ancak tıpkı doğa güzelliğinde olduğu gibi, tasarlanmamış, ilgiden muaf ve kavramdan bağımsız şekilde ortaya çıktığı zaman güzel izlenimi uyandırır (Altuğ, 2007).

"Paradoks, hayalgücünün tanımı gereği kendine ait nesnenin gerçekliğiyle ilgilenmese de kendi nesnesini aslında gerçek bir şey olarak gördü kendine has bir deneyim türünü içermesinde yatar. Öyle hayal gücünün yeterliliklerinin dışında yer alan bu ayrım her nasılsa -hayal gücü hiçbir zaman bir şeyi ispat edemeyeceği için- bir olumlama şeklinde değil de, hayal kurma etkinliği: niteliğini zenginleştiren bir duygu biçiminde, imgelemin ta da içindeymişçesine görünür" (Collingvvood, 2011).

\section{Maurits Cornelis Escher (1898-1972)}

Hollanda'da doğan sanatçı, güzel sanatlar eğitimi aldıktan sonra, kardeşi Berend Esher'in teşvikiyle tarafından matematiğe ilgi duymuştur. Simetri, felsefe ve sonsuzluk gibi ilgi alanlara duyduğu alakanın da etkisiyle, Escher'in yapıtlarında aynı anda kullanabildiği iki ve üç boyutlu kavramlar biçemi ile sonsuzluk fikrini temsil etmeye çalışmıştır. Zaman ve uzay sonsuzluğu yansıtma idealinin onu çalışmalarında motive ettiği düşünebilir. Sanatsal sonsuzluğu temsil etmenin sanatçıda başka yolları da araştırılmıştır. Escher'in eserlerin de sınırlı bir alan içine çeşitli şekiller ters veya negatif pozitif farklılığında 
konmuştur. Diğer bir deyişle, Escher sonsuzluk fikri vermek için kendine has bir çizim ve perspektif tekniği kullanmıştır. Başlangıcı ya da sonu olmayan başka açılardan görülebilen perspektif çalışmalarında paradoksal olarak tek resimde sonsuz sayıda yüklenebilir ve belli bir sınırlılıkla karşılaşmadan süreklilik devam ettirebilir. Kompozisyonların hepsinde belli bir kağıt sınırı bulunmasına rağmen. Bu yönüyle sanatçı oldukça özgün bir yapıtlar serisi gerçekleştirmiştir.

Sınırsızlığın Esher' in eserlerinde bir tema olarak gerçekleştiği görülmüştür (Özellikle bu iki boyutlu sınırsızlık araştırmalarında doğu estetiğinin bezeme figürasyonundan esinlendiği düşünülebilir) Yapıtlarını incelediğimizde izleyici resimlerde sürekli olarak bir hareket algısı ve izlenimi edinmektedir.

Sanatçının eserlerinde zaman mekan ve sonsuzlu tavrının kendine göre gerçekleştirdiğini düşünebiliriz. Bundan dolayı sınırlı kağıt yüzeyde sonsuz bir uzay yaratmıştır. Çalışmalarının çoğunda belirli bir referans noktası bulunmadığını söyleyebiliriz. Esher'in (kavramsal planda) sonlu dünya sınırlarını kullanarak bir sonsuzluk fikri ortaya koymaya çalışmıştır (UsóDoménecha, Nescolarde-Selvaa, Belmonte-Requenaa \& H. Gashb, 2015). (şekil, 1).

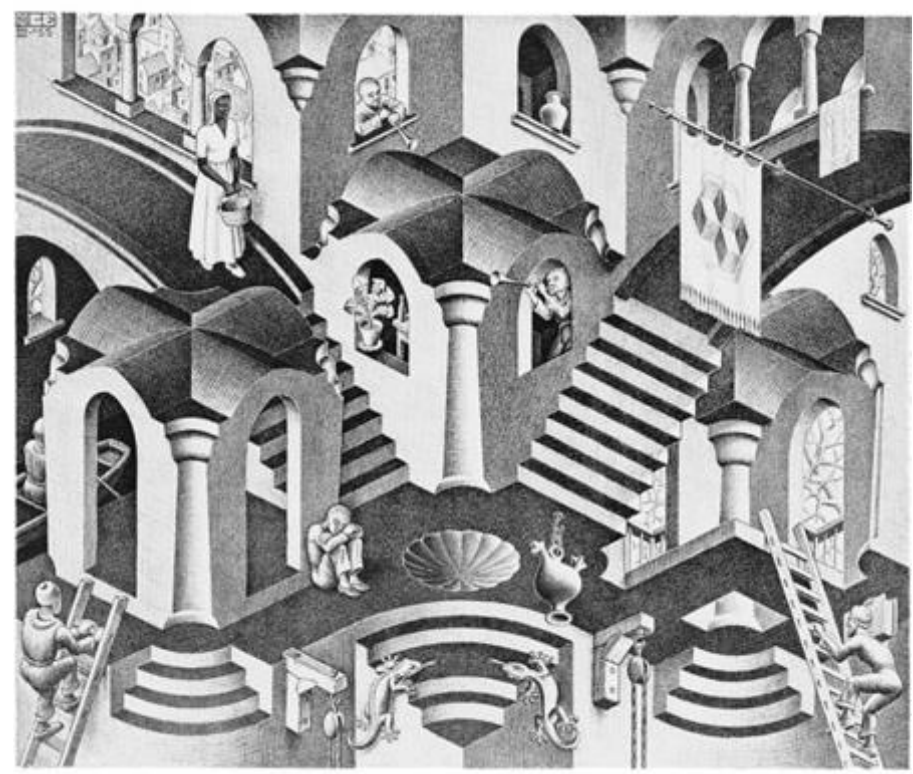

Şekil 1, Artist: Maurits Cornelis Escher,

Title: Convex \& Concave" Large Poster,

Product Code E09

Boyutlar $65 \mathrm{~cm}$ x $55 \mathrm{~cm}$

Availability In stock Poster kâğıdı üzerine siyah basılmıştır. 
Baskı sanatlarında ustalaşmış ressam Escher Paradoksu eserlerinde kullanarak gerçeküstü bir alg1 yaratabilen bir perspektif ifadesinin yanında bu perspektiflerin için de birbiri ile uyumsuz birçok çelişkili unsuru düzenlemeleri içine estetik olarak da dahil edebilmiştir. Dönüşümü de eserlerine katarak çeşitli nesnelerin birbirine doğru evirildiği bir atmosfer yaratan ressam, "Birden fazla anlama gelen resimlerle optik yanılsamalar yaratır. Özel'e (2007) göre, eserleri soyutlama değildir. Yarattığı Paradoks "Gestalt Alg1 Psikolojisi" temel alınarak, Bir şeklin başka bir şekle evirildiği veya tamamen farklılaştığı bir düzen geliştirmiştir.

“... Özellikle perspektifinin bu denli doğru gözükmesi nedeniyle, Hogarth'ın kazı resminin karşıtıdır. Fakat resme daha dikkatli baktı̆̆ımızda, bu türden yapıların bizim gerçekliğimizde yerinin bulunmadı̆̆ını, sanatçının bizi yukarısının ve aşă̆ısının, sağın ve solun söz konusu olmadĭ̆ı düzlemlere götürmeye çallştı̆̆ını anları. Resim, sanatçının uzam sorunu üzerindeki düşünme eylemini içermekte, fakat bununla eşzamanlı olarak uzamın gözleminde izleyicinin oynadl̆̆g rolü de sergilemektedir. Tek tek nesneler ile çeşitli bakış açıları arasında amaçlanan ilişkileri kavramaya çalışırken, sanatçının düzenlemelerinin çelişkili yanlarını da ortaya çıkarmaktayız. "(Gombrich, 2012).

Matematik ve uzay mantığını resimlerinde kullanan sanatçı optik yansımayı da çalışmalarında insanların gündelik nesneleri algılama ve okuma biçimlerinden farklı bir resimleme dili yaratmıştır. Bunlardan biriside Möbiris Şeridi isimli yapıtıdır. ${ }^{3}$, (şekil, 2).

\footnotetext{
3 "Möbius şeridi, geometrik olarak uzunca bir şeridin bir ucunu 180 derece bükerek diğer ucu ile birleştirilmesiyle elde edilen şerittir. İlk olarak 1861'de Johann Benedict Listing tarafından tanımlanmıştır. Dört yıl sonra August Ferdinand Möbius, yayınladığı bir çalışmasında tanımını vermiş, şeridin tek yüzlü olmasını yönlendirilememesiyle açıklamıştır. Normal bir şeridin iki yüzü varken Möbius şeridinin sadece bir yüzü vardır. Başka bir ifadeyle Möbius şeridinin üzerindeki bir noktadan hareket etmeye başlandığında bütün alan taranarak aynı noktaya geri dönülür" ( www.vikipedia.com).
} 


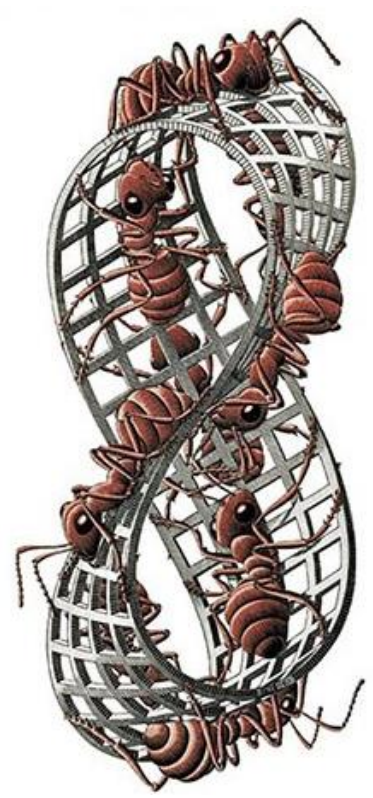

Şekil 2, Artist: Maurits Cornelis Escher,

Title: Möbius Strip II" ( Möbius Şeridi) Large Poster,

Product Code E03

Boyutlar $55 \mathrm{~cm}$ x $65 \mathrm{~cm}$

Printed in color on poster paper (poster kâğıdı üzerine renkler) .

Sanatçı, Uzayın geometrisini ve bizim algılarımız üzerinde yer alan kurgulamasını çeşitli bilindik geometrik yapılar üzerinde gerçekleştirirken, aynı zamanda ayna ve optik araçlardan yansıyan görüntülerinde kompozisyona bir sorunsal olarak eklemektedir.

"Escher'in yapıtlarındaki gibi, yapıları kendi desteklemelerini dışarıda bırakan imkânsız resimlerle mantıksal olarak tezat oluştururlar. Bunlar adeta saf temsiller olarak görülebilir zira, bir anlamda ait oldukları nesneye, bir diğer anlamda ait olamazlar; üç boyutlu uzamdaki hiçbir şeye benzemediklerinden "doğru" da olamazlar. ." (Danto, 2012: 108).

Sanatçı perspektif biliminin kurallarını çalışmalarında farklı yapılarla gözden geçerek yeni bir görsel kurgu yaratabildiğinden yapitlarında birçok kaçış noktası bulunuyor. Bu kaçış noktaları bazen paradoksal oldukları gibi belli bir kurgu ile bulaşarak resmin dinamiğinde ki ana 'çelişki' sorunsalına hizmet etmektedir. Üç kaçış noktasını da aşarak yaptığı bu çalışmalarda özellikle gerçekliğin dışına çıkmaya çağırdığı izleyici yapıtı derinlemesine algılayıp düşünmesini istemektedir. ${ }^{4}$

4 “ ... İsviçreli sanatçı Max Bill de 1936 tarihli heykeli "Sonsuz Kurdele” yi yaparken, yeni bir şekil ortaya çıkardığını düşünmüştü. Möbius şeridi o zamandan bu yana çok sayıda resim-heykel Sanatçı'sı, mimar, edebiyatçı, hatta lunapark tasarımcısına bile esin kaynağı oldu. Şeridin genel biçimi hem M. C. Escher gibi Sanatçı'lar hem de matematikçiler tarafindan oldukça iyi kavranmış 
"Yüzey yapısının bu sürekliliği, Escher'in o olanaksız "Öteki Dünya"sında bile (Gombrich, 2012: 207) varlığını korur: ince çizgilerdeki yoğunlaşmayı, madde bakımından bir bütün oluşturan bir oluşumun geriye kayması diye duyumsarız. Dokunun bize verdiği ipuçları ki bunlara düzenlilik ipuçları da diyebiliriz, bizim için çok güvenilirdir çünkü nesnelerin bu mikro yapısının çeşitli etkilerle değişikliğe uğraması ihtimali çok azdır. Örneğin gözlerimizin önünde uzayıp giden bir kum çölünün zemin yapısının her yerde aynı olduğunu ve kum taneciklerinin aslında bizden uzaklaştıkça küçülmediğini rahatça varsayabiliriz (Gombrich, 2012: 267).

\section{Patrick Hughes (1939)}

"Perspektif ilkeleri ters ve olağanüstü bir şey olur. Heykel resim halinde katılaştığı zaman; Zihin statik bir resim içinde kendi isteğiyle hareket edebilir, imkânsız zanneden elde edilir. " Patrick Hughes

İngiltere doğumlu, öğretmen, yazar, tasarımcı ve görsel sanatç1, "Reverspective" (ters perspektif) Tekniğinin-Akımının yaratıcısıdır. Pompei villarından bu tarafa (Buluntular daha eskiyi de kanıtlayabilir) "Trompe l'oeil" 5 resimler yüzlerce yıldır sanatçılar tarafından üretiliyor (Farthing, 2013). "Gözü aldatmak" anlamına gelen biçemin en önemli özelliği iki boyutlu yüzey üzerine resmedilmiş resmin aslında temsil ettiği şeyin kendisi olduğunun sanılmasıdır. $\mathrm{Bu}$ resimlerde firça darbeleri hissedilmeyecek ustalıktadır. Tek bir açıdan bakıldığında görkemli bir etki yapmaktadırlar (Leppert, 2009). En uzak görünen resmin bölümleri üzerinde yakın bir görüntü elde edilirken, üç boyutlu bir yüzey üzerinde de görüntü ve optik yanıltmasıyla da bir görsel ilizyon uygulanmaktadır. "Reverspective" 6 de önden bakıldığında boyalı ve üç boyutlu perspektife sahip bir yapıt algılanmaktadır. İzleyici başını hareket ederek tablonun 180 derecelik açısında hareket ettiğinde üç boyutlu yüzeyler arasında "optik bir geçiş" olmakta ve görüntü değişmektedir. Diğer tabloya geçiş optik bir algılama ve buna uygun zemin biçimlenmesi ile sağlanmaktadır. Bu hareket derinlik ve güçlü bir disorienting (kafa karıştırma) izlenimi sağlamaktadır. Yanılsama yüzeyi için özel teknikler ve boyamayla (Resimleme) uygulanmaktadır (www. patrickhughes. co. ). Patrick Hughes'un "reverspective" sanatında insan görme sistemi 3-D ile farklı bilgi kaynaklarının etkinliğini araştıran yeni bir yol sağlamaktadır (Rogers, \& Gyani, 2010). Resimsel derinliğin bu biçemi bazı özel perspektif teknikleri ve derinlik algısının

olmakla birlikte, hiç kimse bu biçimi belirleyen, yüzeyin tam olarak neresinden büküldüğünü ve hangi derecede büküldüğünü açıklayan matematiksel denklemleri çözememişti” (Bilim Teknik, 2007).

5 "İşte tam da bu öyle- ama- öyle -değil karakteri sayesindedir ki trompe l'oeil (göz aldatması) aynı anda hem güçlüdür hem debir tür olarak kendi sınırlarını kabul eder. Bir başka deyişle, herhangi bir trompel'oeil'in "konusu" bilfiil temsil edilen şeyden ziyade ikiz temsil ve bakış fenomenleridir." (Leppert, 2009)

${ }^{6}$ Sanatçı tarafından "Reverspectives (ters perspektif) gerçekçi sahneler boyanmıştır." Wagner, Michael, Walter. Ehrenstein, and (Papathomas, 2009). 
anlaşılması için formların yüzeyinde kesik piramitler, takozlar, gibi farklı üç boyutlu geometrik formlar, konstrüksiyon olarak kullanılmış ve üzeri resimlenmiştir. Uzaktaki formların daha yakın gösterildiği bir teknik, izleyicinin hareketleri ile sağlanan aynı tabloda ki görsel algılar, aslında gözlerimizin algısına dayanarak tekrar ve tekrar değişmektedir... (Wade, Hughes, 1999). Sanatçının yapıtlarında görülen özgün ve yaratıcı unsurlardan biriside zengin bir bakış açısı ve fiziksel bir derinlik düzenlemesi yaptığı, özel tekniklerin yanında Konu olarak tasarımın içinde hayali bir derinlik kurgusu ve duyumu oluşturma çabasıdır (Papathomas, 2002).

Yapıtların resimsel yüzeylerine birçok açıdan bakarak ters perspektifi dayalı kurguyu algilarız bu ise bir paradoks olarak aynı resimde farklı iki konu çelişkisi yaratmaktadır. Diğer paradoks ise geri plandaki görüntülerin ters perspektif ile gerçeğe aykırı uygulanmış olmasıdır. Farklı- aynı-ilişkili konulara sahip iki resim aynı tabloda geleneksel metotla boyanmıştır. Yanılsamaların paradoksalın algısı izleyende kuvvetli bir sorunsal yaratır. Şu nedenle ki her açıdan görülen resimler birbiri içinde karmaşa içinde değildir. Bunun yanında ustalıkla yapılan yapıtlar, birbiri içine algılanabilmektedir, (şekil 3,4 ).
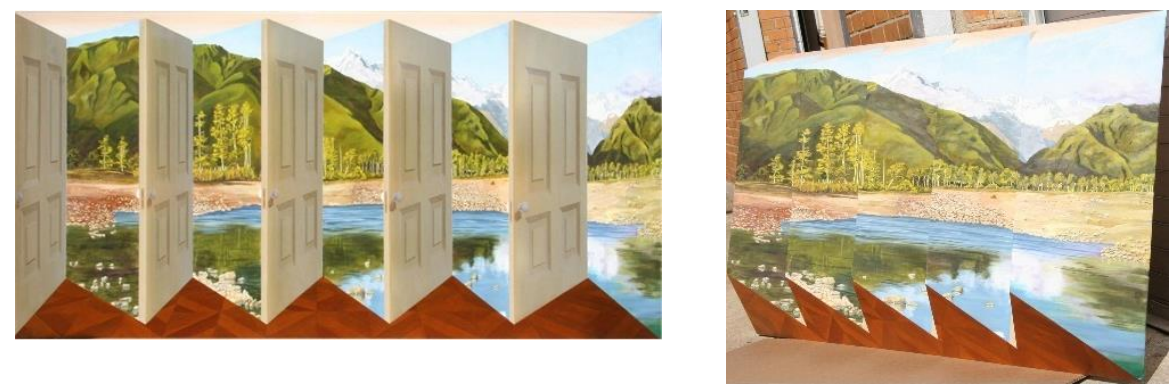

Şekil, 3: Artist: Patrick Hughes,

British (1939 - )

Title: Pleasure Island

Year: 1999

Medium: Oil on Board 3-D Construction

Boyutlar: 38 in. $x 72$ in. $x 8$ in. $(96.52 \mathrm{~cm} \mathrm{x} 182.88 \mathrm{~cm} \times 20.32 \mathrm{~cm})$

Price: On Request 

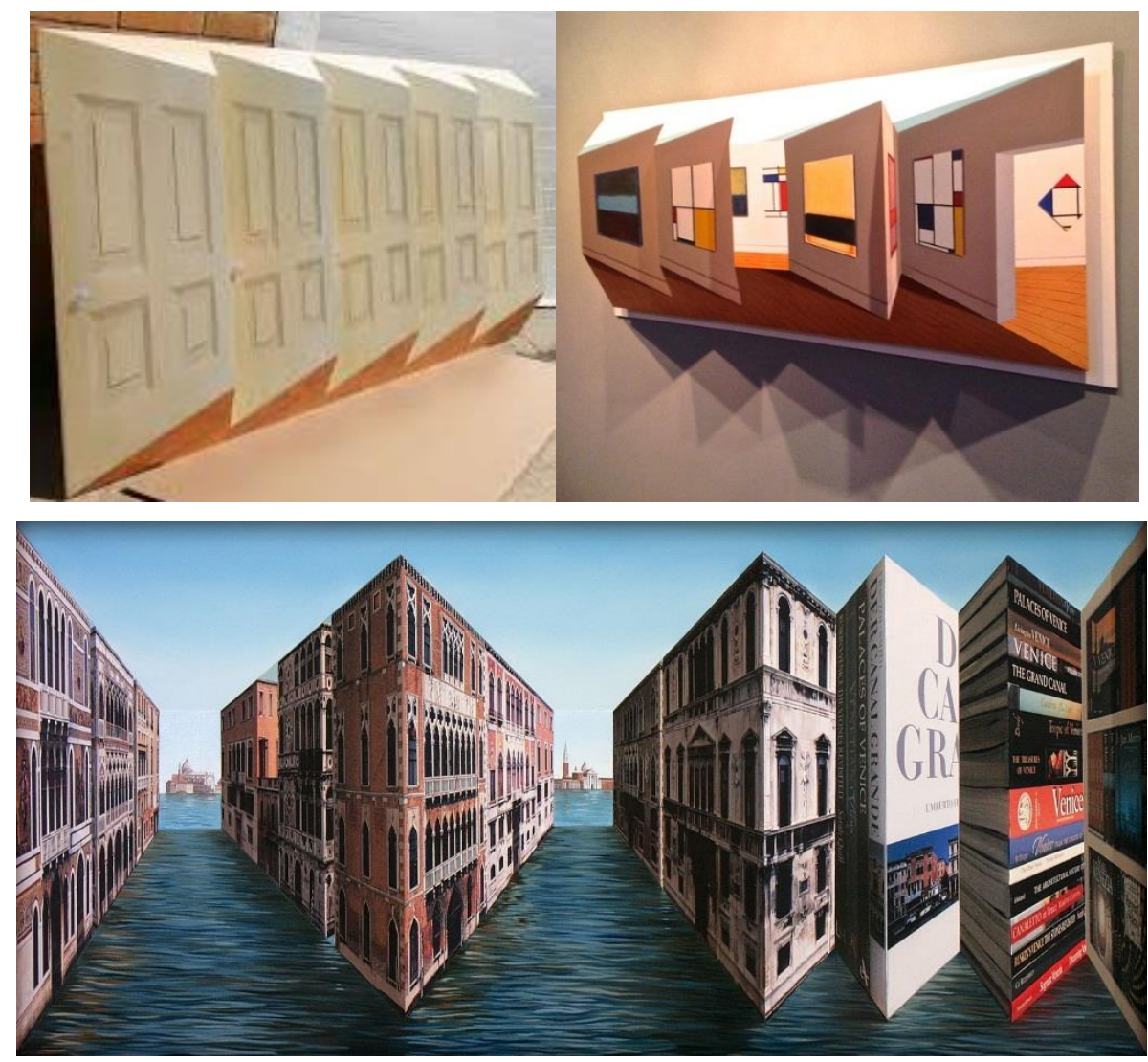

Şekil 4, Artist: Patrick Hughes,

Title: Downtown Uptown

2012 | Edition 5 | Boyutlar: 81 X 192 X $28 \mathrm{~cm} / 32$ x 753/4 x 111/4 y1linda

\section{Rene Magritte (1898-1967)}

"Benim resimlerim hiçbir şey anlatmayan görsel imgelerdir. Akla gizemi getirirler. Doğrusunu isterseniz, benim resimlerimi gören biri kendi kendine şu basit soruyu sorar: 'Bunun manası ne?' O resmin bir manası yoktur. Çünkü zaten gizem de aslında hiçbir şeydir, bilinmeyendir. " (Rene Magritte)

Belçika da doğan, sanat eğitimi aldıktan sonra zaman zaman afiş ve reklam tasarlayan ressam, Gerçeküstücülük akımının en önemli sanatçılarındandır (Neuerbourg, 2005). Resimlerinde birçok gerçeküstü paradoks etrafında tema ve biçimler kullanmıştır. Bu temalarda komedi, korku, cinsellik gibi kavramları tuhaf, ilginç bir şekilde paradoks oluşturacak yeni düzenlemelerle sunmaktadır Şişman'a (2011) göre “Rene Magritte, mantık ve sıra dışı olanların sembolü halindedir." demektedir. 
1926 ve 1938 yılları arasında, Rene Magritte radikal öncülük ederek figüratif resme yeni akademik olmayan bir yaklaşım geliştirmiştir. Daha önce, o yarısoyut bir dizi tecrübe etmişti. Şimdi, o kendini onun bir deyişle, yapma görevin de "Gündelik nesneler, yüksek sesle feryat ediyordu" diyerek kendine ait özgün bir yapıt dili kuracaktır. Magritte'de kullanılan anahtar stratejilere baktığımızda temel olarak "katlama", "izolasyon", "başkalaşım" ile nesneler temsil ediliyor (Umland\& Stephanie\& Alessandro, 2013). Magritte için günlük yaşamdaki gerçeklik paradokslarla doluydu ve farklı yorumlara açıktı. " (Farthing, 2013). "Magritte, resimlerine gizlediği bulmacaları görmeleri için, izleyicinin betimlenen gerçekliğe dikkatle bakması gerektiğini savunmuştur (Farthing, 2013).

Resim konusunda usta firça uygulamaları ve tematik aktarım bakımından gerçek bir uzmandır. Gündelik hayatımızda sık sık karşılaş̧ı̆̆ımız nesneler üzerinden yeni anlamlara ve sorgulamalar yönelttiği çalışmaları bizim bildiğimiz nesnelerle tahayyül etmediğimiz yeni buluşmalar yaratarak, izleyiciye duyumsatmak üzere kurduğu düşünsel paradoksa hizmet etmektedir.

Magritte nin "bu bir pipo değildir" cümlesini yazdığı yapıtı yaygın olarak bilinmektedir. ".. betimlemelerle sözcükleri yan yana getirdiği” ve "bir tabela ressamının yapabileceği bir piponun altına 'Bu bir pipo değildir. Sözcüklerinin" amacı eleştiri görmüş, tartışmalara sebeb olmuştur. "Beklentimize göre, bu sözcükler karşısında ya şaşırırız, ya da onları hemen kabul ederiz. Bu elbette içine tütün konup yakılacak bir pipo değil, Tuval üzerine sürülmüş boyadır. Ama görüntülere baktığımız zaman, böyle sağduyuya dayanan tepkiyi bir yana bırakırız." (Lynton, 2014).

Birçok tartı̧̧ma içerebilecek paradoksal durumda; birçok farklı analiz gerçekleştirilebilir. Resimde görülen bir pipodur. Ama altında yazan yazı bu algımızın yanlış olduğunu belirtir. Sanatçının başlıca mesajı, bizim pipo olarak gördüğümüzün aslında piponun yalnıza bir görüntüsü olduğudur.

"Görüntüler bizde birtakım duygular uyandırdı̆̆ına göre, gösterilenle gösteren arasında gerçekçi bir ayırım yapmamız anlamsızdır. Bir anlamda resimde gördüğümüz pipo, cebimizdeki pipodan daha gerçektir. Çünkü gördügümü̈ şu ya da bu sapı olan, içi kirli ya da ă̆ızlık yerinden bir parça kopmuş belli bir pipo değil, genel bir pipodur. 'Pipo' dediğimiz nesnenin varlı̆̆ını, kafamızdaki pipo kavramı belirler. Kuşkusuz 'pipo' sözcügü bir İniliz ya da Fransız için yeterli olabilir...” (Lynton, 2014).

Magritte'in pipo resminin analizi ve sonuç olarak, paradoksu, pipo altında yazılı (Ceci n'est pas une pipe), 'Bu bir pipo değildir' mesajını da kapsar... "sanat eserimle şaşırtmak istiyorum" sözleri (Ingold, 2011). Bakımından da sanatçının izleyicide belirli bir düşünsel durum yaratmak istediği düşünülebilir. Michel Foucault, Bu Bir Pipo Değildir adlı kitabında bu resmi ve yarattığı paradoksu 
anlatmaktadır. Magritte'nin bu eseri ile artık sanat tarihinde bağlam, arkasındaki fikir ve metin ilişkisi ön plana çıkmış olmaktadır." " (Dikbaş, 2011).

Schier'e (1983) göre, Magritte'nin yapitlarına dair, bu resim pipo değil, soyut bir pipo değil: somut bir pipo değil. Tanrı bilir; bir Dışavurumcu pipo değil, hatta bir Freudyen pipo değil. " Bu bir pipo değildir. Bunu 'Magritte. ' İmzaladı. İşte bu en sapkın sanatçı iştahını doyurmak için yeterli bir paradokstur. Magritte'in betimlemeye çalıştığ gerçekliğin sanatta kendisine yaklaşımın belirli bir paradoks oluşturduğudur. Öyle ki bir pipo resmi ile pipo içemeyiz.

Arhheim ise tablo için daha farklı bir değerlendirme yapmıştır, "Bakan kişi, süprüntünün yüceltilmemiş varlığıyla karşı karşı-karşıya gelir. Gördüğü şey, kuşkusuz düşünmeyi teşvik edebilir, ama düşünce yapıtta değildir." (Arnheim, 2007). Wittgenstein felsefesi ile uğraşmak dilin kendisinden kaynaklanan paradoksları ile bir pipo bir tablo ve bir pipo, olarak her ikisi... Psikanalitik açıdan bakıldığında, vaka yaklaşımı gerektirir. Bu nedenle bilinçsiz dilek, ihtiyaçları ve çözümlenmemiş psikoseksüel çocukluk gelişimi araştırmaları gerekir (Halper, 1999: 208).

Magritte, yeşil elma çalışmaları ile genel anlayışı içinde bir tematik yapıtlar dizisi gerçekleştirmiştir. Yüzünü kaplayan yeşil bir elma ile, bowling şapkası giymiş bir adamı tasvir ettiği (kendisi) resimde paradoksu elma ${ }^{8}$ (kavramı) ile tartışmaya açmıştır. Elmanın arka tarafinda yer alan kendi portresi seyreden kişinin elma ile sanatçı arasındaki ilişkiyi düşünmesini istedi özet olarak sanatçı gizlediği yüzünün merak edilmesini istemiştir. Magritte resim için: "herkes bir şeyler saklar ve insanlar ne sakladığını bilmek ister, ama hiçbir zaman bilemez" demiştir. Paradoks olarak, aynı zamanda arka planda olduğu gibi resmedilen adam ve olduğu gibi betimlenen elma arasında açı olmayan bir ilişki vardır. İzleyici daha fazla gizemi için zorlanmaktadır. Yapıt, Popüler Film ve bilim kurgu romanlarında (A. E. Van Vogt, Isaac Asimov vb.) birçok açıdan tematik etki ve görsel anlatım olanağı sağlamıştır.

Magritte, zihin ve beden ve arasındaki önemli farkı belirterek, bunun tehlikesini kabul eder... Zihin ve beden, sözcükler ve şeyler arasındaki farkları kurulmasında nasıl bir süreç olduğu ile ilgilenmiştir (Simon, 2003). Düşünür olarak anılmak isteyerek felsefeye yoğun bir ilgi duyan sanatçı estetik düzen içinde paradoksal felsefi problemleri tartışarak, sıradan olan ve duyumsanan gerçekliğin sorgulanmasına hizmet eden yapıtlar yaratmıştır... Yenilikçi bir ilke reddetme yerine Magritte, Modernizm sorguladığ 1 içinde olan paradoksu kullanmıştır. Tüm belirgin gerçeklik «Önceki» nesnelerin sunumu paradoksal bir biçemleme dili oluşturmuştur. Magritte'in resim açıklayıcı kalitesi genellikle güçlü bir paradoks ile sonuçlanır. Yapıtların netlik ve sadeliği güzel,

\footnotetext{
${ }^{7}$ Foucault, M. (1995). Bu bir pipo değildir.

${ }^{8}$ Elma resmi sanat tarihinde oldukça önemli bir yere sahiptir. İlk Günah yasak meyve elma sayesinde işlenmiştir. Bu bakımdan dinler tarihi yanında Mitoloji, Din, Estetik, Edebiyat, Plastik Sanatlar, Felsefe, Psikoloji de önemli bir yer tutmaktadır. Elma bu bakımdan sıradan bir meyve değildir.
} 
ama aynı zamanda içindeki görüntüler izleyenleri kışkırtmak için hazır durumdadır (www. theartstory. org), (Şekil 5, 6).

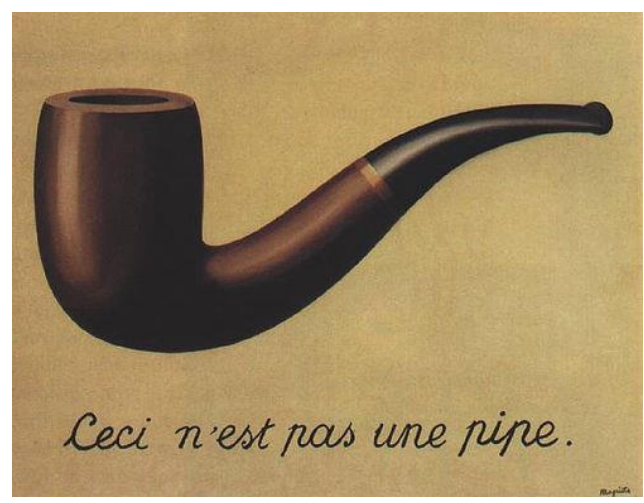

Şekil 5, Sanatçı: Rene Magritte,

Title: La trahison des images, Y11, 1928-1929, Teknik: Tuval üzerine yağliboya, Boyutlar, 63, $5 \mathrm{~cm} \times 93,98 \mathrm{~cm}(250 \mathrm{in} \times 3,700$ in), Yer: Los Angeles County Güzel Sanatlar Galerisi, Los Angeles, California

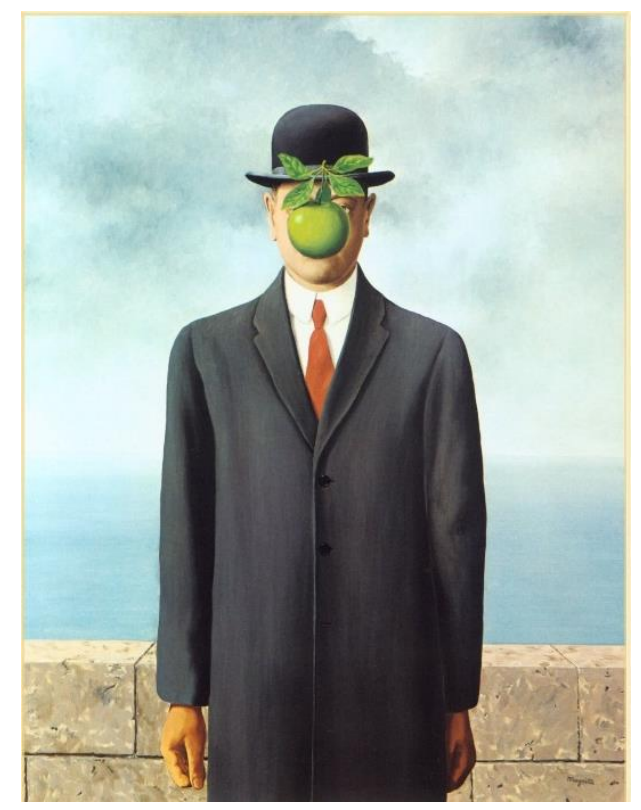

Şekil 6, Artist: Rene Magritte,

Title: The Son of Man

Bitiş Tarihi: 1964, Yaratılış Yeri: Belçika, Stil: Gerçeküstücülük, Dönem:

Sonra Dönem, Tür: otoportre, Teknik: Tuval üzerine yağlıboya, Malzeme: tuval, Boyutlar: 116 x $89 \mathrm{~cm}$, Galeri: Private collection 


\section{Chema Madoz (1958)}

1958 y1lında Madrid'de doğan Chema Madoz, İspanyol fotoğrafının önemli isimleri arasında yer almaktadır. 1980-1983 yılları arasında Madrid Üniversitesi'nde Sanat Tarihi öğrenimi gören sanatçı, fotoğrafçılığa da bu yıllarda başlamıştır. Fotoğraflarında günlük hayatın içinde yer alan sıradan nesneleri Sürrealist (gerçeküstü) estetiğin elemanlarını da kullanarak kendine ait bir dil oluşturmuştur. (www. millireasuranssanatgalerisi. com). Madoz'un çalışmalarında da "M. Heidegger", J. Derrida ve M. Schapiro" gibi düşünürlere göndermeler vardır (Lopez, 2011).

Fotoğraflarında görülen nesneler gerçeklik bağlamından kopartılarak humour (mizah) düzleminde farklı bağlamlara taşınır. Chema Madoz, fotoğraflarında paradoks ve eğretileme (metaforların) incelikli oyunlarıyla adeta görsel bir şiire imza atar. Sanatçının bunu yaparken en sıradan nesneleri değiştirerek, onları işlevselliklerinden, bağlamlarından ve günlük kullanımlarından çıkartarak, başkalaştırarak, gerçekliği sorgulamaya girişir. İzleyiciyi ise gözlem ve yorum yapmaya bu nesnelerdeki gizli şiiri keşfetmeye davet eder (www. millireasuranssanatgalerisi. com). Fotoğraf gündelik nesnelerin ince ve ironik bir yol ile paradoksal dünyalar göstermektedir. Diğer nesnelere, yeni bir yorumla oynak etkileşim yoluyla ve olsun Tanıdık nesneleri bir işlev ötesinde, yeni bir bağlamda yerleştirilir. $\mathrm{Bu}$ tasarımlar gerçeklik sayesinde bizim algılarımızla oynamak ve onu yüceltmek için şiirsel bir şekilde ortaya koyuştur (Madoz, 2013). Madoz fotoğraflarını insanların görmesi ile görsel algı ile beyin ve deşifre arasındaki gerilimi yaratmıştır. Onun fotoğrafları kendi içinde isimsiz bir paradoks bulunmaktadır. Siyah beyaz fotoğraflarda Gerçeklikten soyutlamaya başka bir sahne vardır (www. famousphotographers. net/chemamadoz). Paradoks niyetli çalışmalarını görmek ve anlamak, mizahi, saçma, paradoksal ve oldukça çarpıcıdır. Çevremizdeki her şeyin sanat olduğunu örneklemek ve göstermek istiyor (www.stylecrave. com). Madoz'un görüntüleri yaşamdaki koşullarla güç, hayal, gibi paradoksal bir tartışma barındır. Yapıtlarında 1şık anahtar kavramlardan birisidir. Doğal ışığı tercih etmektedir. Çizim ve nesneler üzerinde yaptığ çalışmalarla görüntüyü bir heykeltıraş gibi analiz eder, oylumlar. Buna rağmen Madoz'un savunduğu fotoğraftır. Ve estetiği kendi gerçeğini barındırır (www. ca2m. org/en/publications). Nesne ve anlamı, ya da daha iyisi, birçok arasında yorumlar yapmaktadır. Eserlerinin Her bir görüntüsü, kendi içinde bilinçli yapıllyor. Kendi dünyası, bize gerçek dünyada her iş göründüğü gibi değildiri duyumsatıyor. Çünkü anlamların çokluğu onun yaratılış derinliğini ve nesnelerin iç morfolojisi derinliğini artırıyor. Madoz birçok kurguyu bir şair gibi tasarımlıyor. Şeyler arasındaki gizli ilişkileri nasıl bulacağını araştırıyor. Uzlaşmazla, uzlaştıran şiirsel görüntü budur. Farklı dünyalar bize yeni bir varlığı oluşturmak için izin veriyor (Saravo: 2011).

\footnotetext{
${ }^{9}$ www.highlike.org/text/chema-madoz-3
} 
Madoz'un fotoğraflarına bakıldığında tuhaflık ve aşinalık kavramları birbiri içine girmiştir. İşler tuhaftır, çünkü ilk bakışta izleyeni şaşırtır. Şoka uğratır. İşlerindeki aşinalık ise kullandığı referansların izleyicinin anında tanımasından gelir. İzleyicinin Madoz'un fotoğraflarındaki keşfi, sanaţ̧ı ile ortak noktaları olduğunu hissetmesine neden olur. Bu durum, fotoğraflarla rahat bir şekilde diyalog kurmanıza da yardımcı olur. Chema Madoz fotoğrafı, çevresiyle ilişkisini yeniden tanımlamak içinde kullanır. İşlerinde kendi seçtiği ve kendisinin kurguladığ 1 bir ortamda düzenlediği nesnelerin alışılmadık mevcudiyetlerine odaklanır ve bu odaklamayı da siyah-beyaz olarak fotoğraflar. Böylece Chema Madoz'un makinesinden çıkan enstantaneler her defasında izleyici tarafindan yeniden okunmaya açık hale gelir. " (www. millireasuranssanatgalerisi. com/sergiler/chema-madoz), (şekil 7, 8).

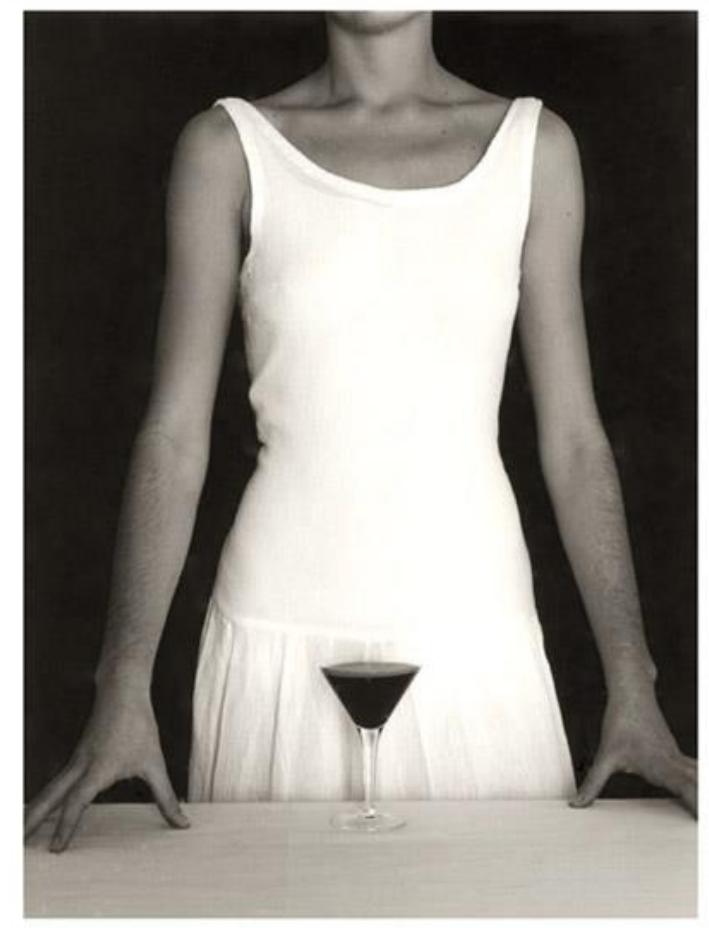

Şekil 7, Artist: Chema Madoz

Tittle: Voman

Fotografía (fotoğraf) B/N s/papel baritado virado al sulfuro (baryum sülfür tonlama kağıdı)

Boyutlar: $60 \times 45 \mathrm{~cm}$, Edición abierta

Firmado y numerado al dorso 


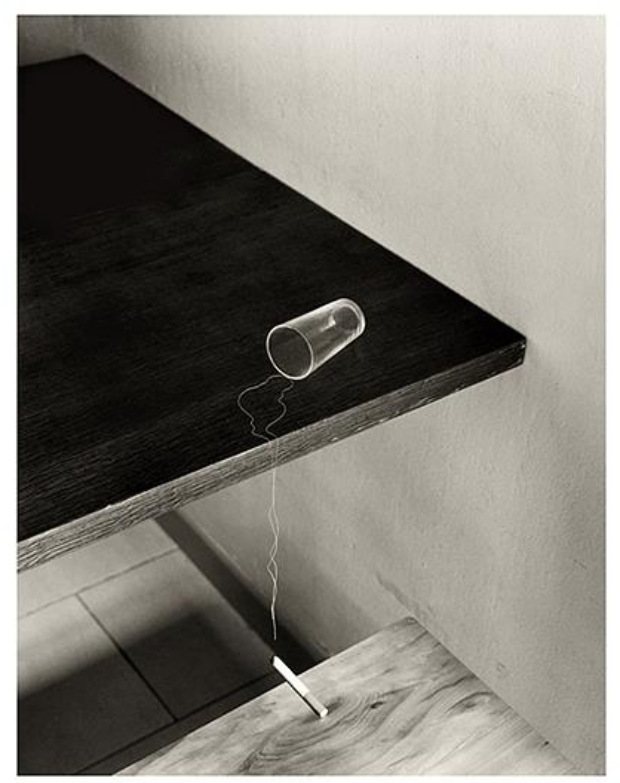

Şekil 8, Artist: Chema Madoz S/t, 1987

Title: Without

Fotografía B/N s/papel baritado virado al sulfuro

Boyutlar: 60 x $45 \mathrm{~cm}$, Edición abierta

Firmado y numerado al dorso

\section{Ignatius Widiapradja (1960)}

Endenozya doğumlu, öğretim üyesi, tasarımcı ve ressamdır. Sanat eğitimini Amerika'da almıştır. Amerika Texas'da çalışmalarını sürdüren ilahi paradoks adlı bir dijital fotoğraf serisi uygulamıştır (www.drake.edu). Boyama ve yaratıcı dijital çalışmaları güncel sanat içinde sayılmaktadır. Genellikle çalışmalarında çok boyutlu bir gerçek üzerinde yer almıştır. Bu boyutlar arası çalışmalarında birçok gerçeğin periyodlar halinde görebiliriz. Bu görüntülerde anılar, cinsellik, duygular, arzu, uzay mekân gibi gerçekleşmesi gündelik hayatta mümkün olmayan birçok görüntü bir arada kullanılarak bir paradoks yaratılmıştır. Kompozisyonlarında manzara, gezi, doğa atölye ve görsel sanatlardan birçok biçimi birleştirmektedir. Özellikle serilerinde etkilendiği doğu estetiği ve coğrafyasından Himalayalar, Endonezya, Nepal, Butan, Budist tapınaklar gibi temsillerde yer almaktadır (www.zoominfo.com). Eserlerinde boyama ve dijital baskı öncelikle tercih ettiği tekniklerdendir. Eserlerinde yapılar, mekânlar ve toplamda görüntüler süreli bir akış içerisindedir. Üst üste kullandığı ve anıları ile birleştirdiği çok boyutlu süreçsel ilişkiler vardır (www.artandartdeadlines.com). Sanatı ve yapıtları için şöyle demektedir; benim çalışmalarımda, görüntü ve mekânsal yapı ve eklemler sürekli bir akış hali sergileyen bir yapışkan olarak çok boyutlu bir gerçekliği oluştururlar. Bu 
çakışmalar da anıların örtüşmeleri, gelecek projeksiyonları ve çok boyutlu süreçler var. Bizim anılarımızdaki, görüntüler olaylar ve duygular ve iç içe bulunuyor ve ayrılamaz. Onlar mozaikler olarak, uzay zaman sürekliliğindedir (www.dailypalette.uiowa.edu), (Şekil 9, 10).

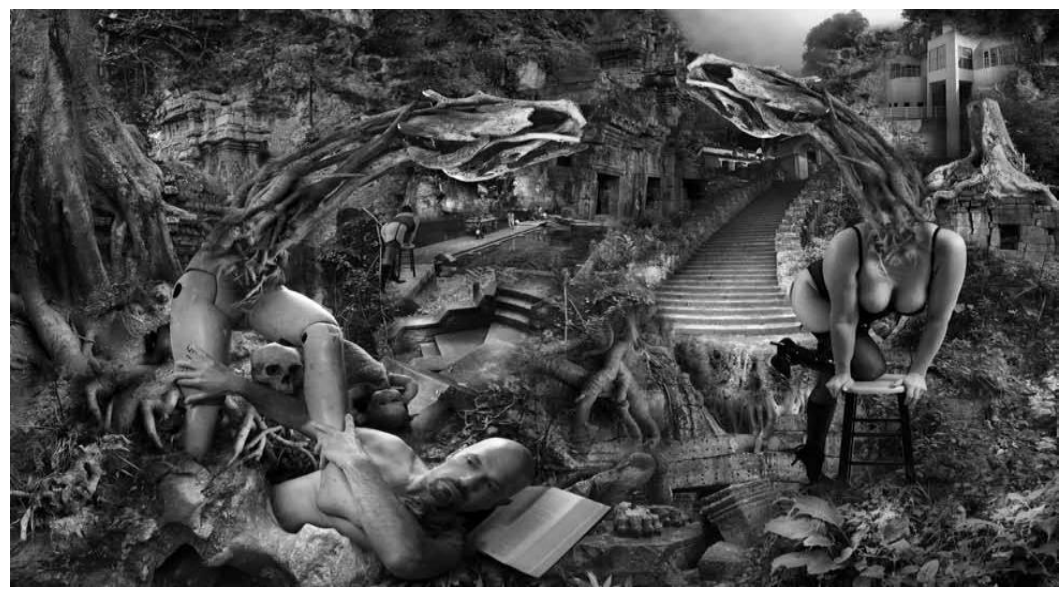

Şekil 9, Artist: Ignatius Widiapradja

Title: "Coincidentia Oppositorum: A Divine Paradox"

$24 \times 36$ inches $(61 \times 91.4 \mathrm{~cm}$. )

gnatius Widiapradja - Digital

Series - 2012

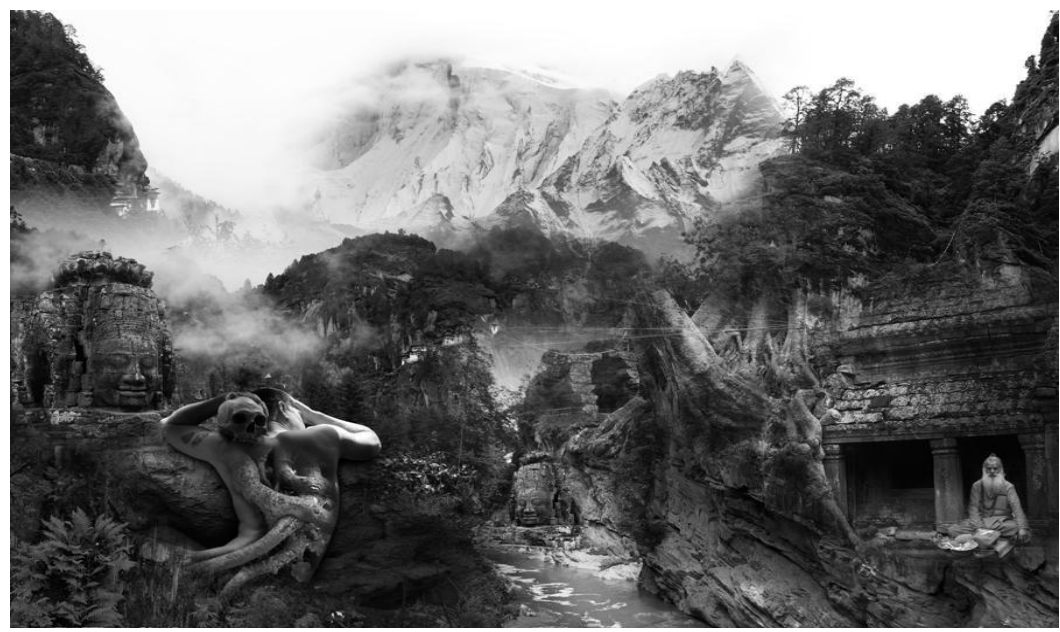

Şekil 10, Artist: Ignatius Widiapradja

Title: "Coincidentia Oppositorum: A Divine Paradox"

Buddha Series

Available as 18" x 12", 36" x 24", or

Boyutlar: 54" x 36" prints

gnatius Widiapradja - Digital

Series - 2012 


\section{Sonuç}

Tavır olarak izleyici üzerinde paradoks algısı oluşturmak isteyen birçok görsel sanatçı vardır. Makale konusu seçtiğimiz beş sanatçı; Partıck Hughes, Maurits Cornelis Esher, Ignatius Widiapradja, Rene Magritte, Chema Madoz' da bu sanatçılardandır. C. Madoz, yalnızca fotoğraf yapıtları üzerinde çalışmaktadır. I. Widiapradja, fotoğraf ve resim üretmeyi tercih eden bir sanatçıdır. Diğer sanatçıların önemli eserleri resimlerden oluşmaktadır.

$\mathrm{Bu}$ sanatçılar içinde bir sınıflama yapılırsa P. Hughes, optik algıyla oluşturulan bir paradoks, M. C. Esher, kâğıt üzerinde kendi oluşturduğu boyutlar ve uzay zaman mekân paradoksu, I. Widiapradja, katmanlara birçok anlam yükleyerek yoğun ve atmosferik görüntülerle oluşan bir paradoks, R. Magritte, düşünür tavrı ile sade uygulamalarının ile simge ve imge iletişiminden oluşturduğu bir paradoks, C. Madoz ise farklı nesneleri ince bir zeka ile paradoksal bir şekilde biçimlendirerek izleyenlerde bir düşünme iklimini kurmaya çalışmışlardır.

Sanatçılar, farklı teknik ve biçemlerle yapıtlarını yaratmışlar ve alımlayıcıları paradoks kurgusu ile düşündürüp sorgulama gerçekleştirmelerini sağlamaktır. Sanatçıların yapıtları analiz edildiğinde, Paradoksun içerdiği mesaj-anlam sanatçı tarafinda belirli ve kasıtll bir biçimlendirmeye tabi olmuştur. Varsayımda bulunulabilir.

Paradoks ya da çelişki genel de olumsuz ve mantık dışı gibi bilinmektedir. Sanat yapıtında ki pardadoks betimlemesine yapılan eleştirilerde dikkatli olmak gerekir. Paradoks yaratmak için sanatçilar bütün düşünsel yetenekleri kullanmaktadırlar. Paradoksun betimlenmesi alımladığında sıradanlaşmış ve semantiği sınırlanmış birçok görüntü yeni bir anlatım dili kazanır. Yapıtı alımlayanlarda şaşkınlık merak ve düşünsel bir süreç meydana gelebilir. Daha sanatçı tarafından yapıtın ortaya çıkarılma amacı ve sürecinde yer alan bu unsurlar, sınırlarını izleyicinin belirleyebileceği bir düşünce iklimi yaratarak paradoks üzerinden gerçek sorunsalını tartışmaya açıyor.

Görsel Sanatçılar tarafindan paradoksu içeren yapıtlarda gerçeklik ters düz edilmiş̧ olabilir. Sanatçı estetiği bakımından yeniden biçimlendirmiştir. Gerçekliğe ulaşmada alımlayıcı paradoksal bir betimleme ile de sanat yapıtı amacına ulaşabilir. Bu yeni biçim alımlayıcıda daha düşünsel ilgi ve yorumu kışkırtır. Bu nedenle Sanatçı tarafında da paradoksun yapıtı yaratmada yaratıcı bir işleve hizmet ettiğini söylemek için elimizde yeterince veri vardır. Gerçekliği betimlediği düşünülen yapıtların neyi ve ne biçimde resmettiği tartışma içerir.

Paradoks, sanat yapıtının kurgusunun özgünlüğ̈nü ve aktarılan mesajının biricikliğini sağlayıp gerçeği sezmemizi sağlayabilir. Fakat sanat yapıtını alımlayanların algıları birbirlerinden farklılıklara sahiptir. Alımlayıcının etkenedilgen bir şekilde sanat yapıtı üzerinde değerlendirme yapar. Sanat yapıtından ulaşılacak gerçeğin hangi ölçüde görünür hale geldiği tartışma içerir. Ve bu tartışılma sanat var olduğu sürece var olacaktır denilebilir. 
Sonuç olarak sanat yapıtının duyurduğu ve sanatçının amaçladığı estetik içinde paradoksu alımlatmak sanatçı için bir zarurettir. Gerçekliğin alımlayıcı tarafindan sezilmesi sanat yapıtı sayesinde olabilecektir.

\section{Kaynakça}

Danto, A. C. (2012). Sıradan Olanın Başkalaşımı, Ayrıntı Yayınları, İstanbul.

Hanson, A. (2000). Ed: Jane Clarke, Antonia Contro, Esther Grisham, Cori Wulf, Produced by the Department of 'Museum Education The Art Institute of Chicago.

A. Kalay \& F. Göksu, (2003). "Reklam ve Paradoks", Gazi Üniversitesi-İletişim Fakültesi Dergisi, say1: 18, 59-71.

Simon. A. (2003). "Love and surrealism: René Magritte and André Breton in 1929. "Word \& Image 19. 3: 214-222.

Şişman, A. (2011). Sanata ve Sanat Kavramlarına Giriş, Literarür yay. İstanbul.

Vural, A. (2008). Fizik Paradoksları, Bilim Teknik 2008, Fizik Paradoksları, Bilim Teknik. P: 3.

Rogers, B. \& Gyani, A. (2010). Binocular Disparities, Motion Parallax, And Geometric Perspective İn Patrick Hughes's 'Reverspectives': Theoretical Analysis And Empirical Findings. Perception, 39 (3), 330.

Bilim Teknik, (2007). Editör, Ağustos, çev. Türkiye, s:15.

Madoz, C. (2006). 2000-2005, Premı Nacional De Fotografía 2000. Ministerio de Cultura Catalogue, Mueso Barjola, Asturias, İspanya. s:8

Madoz, C. (2013). Soloexhibition, 19th September - 11th December, The Exhibition Was Curated By Tomás Rodríguez Soto. 5

Madoz, C. (2014). Exhibition open cards, Galería Elvıra González, Galería Elvira González Gloria Borrego c/ General Castaños, 3 28004-Madrid, 1.

Gombrich, E. H. (1992). Sanat ve Yanılsama. Ahmet Cemal (çev), Remzi kitab., İstanbul, 207, 239, 267.

Schier, F. (1983). This Is Not a Pipe, Book Abstract, January, The New York Times, 23.

Collingvvood, G. (2011). Kisaca Sanat Felsefesi, Bilge Su, Ankara, 50.

Neuerbourg, H. (2005). Magic of Magritte: A Paradox in The Works October 08, Associated Press, Los Angeles Times.

Hacınebioğlu, İ., L. (2006). Bir Düşünce ve Mantık Problemi Olarak Paradoks, Uludağ Üniversitesi Fen Edebiyat Fakültesi Felsefe Dergisi Kaygi, Yıl 2006, Cilt-Güz, Say1-7, 106, Bursa.

Doménecha, J. L. \& Usó-, Nescolarde- J., S., \& Belmonte-Requenaa M. \& Gashb H. (2015). Cybernetics and Systems: An International Journal Volume 46, Issue 6-7, Special Issue: Belief Systems in Science and 
Engineering, Walking Through Cantor's Paradise and Escher's Garden: Epistemological Reflections on the Mathematical Infinite (II), DOI: 10. 1080/01969722. 2015. 1038474, pages: 438-451.

Helfenstein, J., \& D'Alessandro, S, \& Umland A, (2013). Magritte the mystery the ordinary, 1926-1938, Published by The Museum of Modern Art, New York, pages:7.

Halper, F. (1999). Construals: Perceptual Occlusion In The Work Of Rene Magritte, publzshers. Prznted in the netherlands, K. Academac, pages: 208.

Foucault, M. (1995). Bu Bir Pipo Değildir. Yapı Kredi, İstanbul.

Lopez, M., R. (2011). "To Be İn Someone's Shoes" Un Acercamiento Al Debate De Los Zapatos De Van Gogh En La Teoría Del Arte Contemporáneo, Bajo La Dirección De La Doctora, Madrid, Septiembre, Unıversidad Complutense De Madrid, Facultad De Bellas Artes, pages: 69.

Hikmet, N. \& Dikbaş, R. (2011). İmge ve Metin: Yazı ve Resim Nasıl Bir Araya Gelir?, Sayı: 75 - yıl:, bilim ve sanat vakfı, Baskı Kurtiş Matbaacılık, İstanbul.

Lynton, N. (2014). Modern Sanatın Öyküsü, Remzi, İstanbul.

Saravo, O., S, (2011). Chema Madoz, Odalys Galería de Arte, catalogue, Caracas 1, Venezuela.

Arnheim, R. (2007). Görsel Düşünme, Metis Yay, İstanbul.

Leppert, R. (2009). Sanatta Anlamın Görüntüsü: İmgelerin Toplumsal İşlevi: Ayrıntı Yayınları, İstanbul.

Rothman, R. (2007). Konsthistorisk Tidskrift, Journal of Art History Volume 76, Issue 4, A Mysterious Modernism: René Magritte and Abstraction, 224-239.

Farthing, S. (2013). Sanatın Tüm Öyküsü, Hayalperest Yayınevi, İstanbul.

Altuğ, T. (2007). Kant Estetiği, Payel Yay., İstanbul, 182.

Ingold, T. (2011). Being Alive, Essays on movement, knowledge and description, Y Published İn The Usa \& Canada, , Seven Variations On The Letter A, 182-183.

Papathomas, T., V. (2002). Experiments on the role of painted cues in Hughes's reverspectives. Perception-London-, 31(5), 521-530.

Türkoğlu, Ü., N. (2000). Görüyorum , Gündelik Yaşamda İmgelerin Güç, Der Yay.

Michael, W., \& Ehrenstein, H. \& Papathomas, T. V.. (2009). "Vergence in reverspective: Percept-driven versus data-driven eye movement control.

" Neuroscience letters, 449. 2, 142-146. 
W. Nicholas \& P. Hughes, (1999). Fooling the Eyes: Trompe l'oeil And Reverse Perspective. Perception-London-28, Pages: 1115-1120.

Özel, Z. (2007). Op Sanat Ve Dijital Teknolojinin Kullanımı, Anadolu Un1versity Journal Of Social Sciences cilt/vol. : 7- say1/ no: 2: 395-418., Eskişehir.

\section{Internet Kaynakçası}

www. artandartdeadlines. com/2012/09/call-for-entries-12-12-international, 1 Eylül 2015 Tarihinde İnternetten indirilmiştir.

www. ca2m. org/en/publications-2/item/313-sin-titulo-atlas, 19 Temmuz 2015 Tarihinde İnternetten indirilmiştir.

www. famousphotographers. net/chema-madoz, 17 Temmuz 2015 Tarihinde İnternetten indirilmiştir.

www. millireasuranssanatgalerisi. com/sergiler/chema-madoz, 11 Temmuz 2015 Tarihinde İnternetten indirilmiştir.

www. moberggallery. com/Ignatius_interview. Shtml, 21 Temmuz 2015 Tarihinde İnternetten indirilmiştir.

www. patrickhughes. co. uk/reverspective), 14 Temmuz 2015 Tarihinde İnternetten indirilmiştir.

www. stylecrave. com/2009-01-16/chema-madoz-beyond-talent, 9 Temmuz 2015 Tarihinde İnternetten indirilmiştir.

www. TheArtStory. org ziyaret, 7 Temmuz 2015 Tarihinde İnternetten indirilmiştir.

www. widiapradja. com, 4 Temmuz 2015 Tarihinde İnternetten indirilmiştir.

www. zoominfo. com., 1 Temmuz 2015 Tarihinde İnternetten indirilmiştir.

www. dailypalette. uiowa. edu/?artwork=3070, 6 Temmuz 2015 Tarihinde İnternetten indirilmiştir.

\section{Görsel kaynakça:}

E. Doğan (2004). Temel Tasarıma Çağdaş Yaklaşım, Mor Ajans Reklam ve Tanıtım, İstanbul. www.tr.wikipedia.org/wiki.

www.moma.org/collection.

www.art-collecting.com/galleries_ca_losangeles.htm 